\title{
Aplikasi Jaringan Saraf Tiruan Backpropagation untuk Memprediksi Prestasi Siswa SMA (Studi kasus: Prediksi Prestasi Siswa SMAN 4 Ambon)
}

\author{
Y. A. Lesnussa, S. Latuconsina, E. R. Persulessy \\ Jurusan Matematika, Fakultas MIPA, Universitas Pattimura \\ Jl. Ir. M. Putuhena, Kampus Unpatti, Poka - Ambon \\ Email:yopi_a_lesnussa $@$ yahoo.com
}

\begin{abstract}
ABSTRAK
Mutu dan kualitas dari suatu institusi pendidikan salah satunya dilihat dari prestasi yang dicapai oleh lulusannya. Salah satu criteria penilaian untuk menilai prestasi lulusan pada tingkat sekolah dasar sampai pada sekolah menengah yaitu melalui NEM. Nilai pada NEM ini sering dijadikan ukuran untuk menilai para siswa yang akan masuk pada suatu jenjang pendidikan berikutnya. Selain itu, penerimaan siswa di suatu jenjang pendidikan juga disesuaikan dengan daya tampung dari sekolah dimaksud. Nilai NEM di jenjang SMP yang tinggi, ternyata tidak menjamin prestasi siswa di jenjang SMA. Sehingga penelitian ini bertujuan untuk memperoleh pola keluaran prediksi prestasi siswa SMA Negeri 4 Ambon yang berkorelasi antara NEM dan total Nilai siswa SMA kelas X (sepuluh) sesuai dengan data yang dilatihkan menggunakan aplikasi Jaringan Saraf Tiruan metode Backpropagation. Jaringan Saraf Tiruan ini menggunakan Arsitektur Multilayer Net yang meliputi 4 unit sel lapisan masukan, satu lapisan tersembunyi dengan jumlah unit sel yang ditentukan secara acak, dan satu lapisan keluaran berjumlah satu unit sel sebagai target. Data yang diambil berupa NEM siswa dan total nilai siswa semester pertama kelas X. Selanjutnya data dianalisis dengan menggunakan JST metode Backpropagation, dengan bantuan software MATLAB. Hasil penelitian ini menunjukkan bahwa korelasi antara NEM dan total nilai siswa semester 1 kelas X cukup baik dengan eror yang kecil. Untuk mempermudah perhitungan didesain suatu toolbox Matlab dengan menggunakan GUI Matlab.
\end{abstract}

Kata kunci: Jaringan Saraf Tiruan, Backpropagation, Prestasi siswa, Nilai NEM.

\begin{abstract}
The quality of an educational institution can be seen by the achievements of its graduates. One of the assessment criteria to assess the achievements of graduates from primary school level to the high school that is through the NEM. The value of the NEM is often used as a measure to assess the students who will go to the next level of education. In addition, enrollment in an education adjusted by the capacity of the schools. The NEM value in the junior high level, it did not guarantee the achievement of students at the high school level. Thus this study aims to obtain output patterns predictive of student achievement in SMAN 4 Ambon correlated between NEM and the total value of Senior high school students of class $X$ (ten) in accordance with the data that was trained to use applications Neural Networks Backpropagation method. Artificial Neural Network Architecture Multilayer Net uses the included 4 cell unit input layer, one hidden layer with the number of unit cells is determined at random, and one layer of output amounted to one unit cell as a target. The Data taken the form of NEM students and the total value of students' first semester class X. Furthermore, the data were analyzed by using ANN Backpropagation method, with the aid of MATLAB software. The results showed that the correlation between NEM and the total value of the 1st semester students of class $X$ is quite good with a small error. To simplify the calculation designed a toolbox Matlab by using GUI Matlab.
\end{abstract}

Keywords: Artificial Neural Networks, Backpropagation, Student Achievement, NEM Value.

\section{Pendahuluan}

Penerimaan siswa baru merupakan suatu kegiatan rutin yang diselenggarakan oleh pihak sekolah setiap tahunnya dengan berpegang pada prinsip objektivitas, transparansi, dan akuntabilitas. Proses penerimaan siswa baru dilaksanakan setiap awal tahun ajaran baru dengan sistem terbuka dan diketahui oleh masyarakat luas, tidak membedakan asal - usul 
suku bangsa, agama, ras, maupun golongan sehingga penyimpangan dapat dihindari dan dapat dipertanggungjawabkan kepada masyarakat, baik menyangkut prosedur maupun hasilnya.

Pada dasarnya tidak ada penolakan dalam penerimaan siswa baru. Namun karena disesuaikan dengan daya tampung tiap sekolah maka dilakukan seleksi terhadap para calon peserta didik berdasarkan peringkat Nilai Ebtanas Murni (NEM) Sekolah Menengah Pertama (SMP) apabila jumlah calon peserta didik melebihi daya tampung sekolah. Seleksi ini dilakukan berdasarkan asumsi bahwa jumlah NEM yang tinggi diprediksi akan melebihi prestasi yang baik pada saat sekolah di SMA nanti. Memprediksi prestasi siswa dengan sistem konvensional pada saat penerimaan siswa baru dengan memperhatikan jumlah NEM dan Surat Tanda Tamat Belajar (STTB) sekolah asal merupakan langkah yang belum tentu benar, karena jumlah NEM yang tinggi tidak menjamin akan berprestasi di SMA.

Sistem seleksi secara konvensional ini merupakan konsep awal suatu metode untuk memprediksi prestasi siswa dengan menggunakan alat bantu komputer didukung dengan pendekatan jaringan saraf tiruan. Hingga saat ini sistem prediksi secara konvensional belum diuji seberapa besar akurasi ketepatan prediksinya, dengan jaringan saraf tiruan, komputer difungsikan sebagai alat untuk memprediksi prestasi siswa dengan tidak mempertimbangkan faktor lain penyebab kemerosotan atau peningkatan prestasi siswa, misalnya karena faktor lingkungan, guru, motivasi belajar, fasilitas, dan lain-lainnya. Ke depan, faktor yang mempengaruhi tersebut dapat dijadikan sebagai variabel pendukung dengan identifikasi parameter yang jelas.

Prediksi prestasi dalam penelitian ini adalah mencari hubungan antara NEM dengan jumlah nilai pada semester pertama setiap siswa, dengan demikian diharapkan akan muncul suatu pola di mana dengan pola masukan NEM tertentu maka aplikasi pada komputer akan dapat memberikan pola keluaran prediksi sesuai dengan data yang dilatihkan, dan untuk mempermudah melakukan penelitian ini, digunakan program Matlab. Karena Matlab memiliki fitur - fitur yang dapat digunakan untuk menganalisis secara lebih praktis, efektif dan efisien.

Adapun tujuan yang ingin dicapai dari penelitian ini adalah untuk memperoleh pola keluaran prediksi prestasi siswa SMA yang berkorelasi antara NEM dan total Nilai siswa SMA kelas X sesuai dengan data yang dilatihkan.

\section{Metode Penelitian}

\section{Definisi Jaringan Saraf Tiruan}

Jaringan Saraf Tiruan (JST) merupakan salah satu representasi buatan dari otak manusia yang selalu mencoba untuk mensimulasikan proses pembelajaran otak manusia tersebut (M.F Andrijasa, 2010). untuk JST tercipta sebagai suatu generalisasi model matematika dari pemahaman manusia (human cognition) yang didasarkan atas asumsi pemrosesan informasi terjadi pada elemen sederhana yang disebut neuron. Isyarat mengalir diantara sel saraf melalui suatu sambungan penghubung, setiap sambungan penghubung memiliki bobot yang bersesuaian dan setiap sel saraf akan merupakan fungsi aktivasi terhadap isyarat hasil penjumlahan berbobot yang masuk kepadanya untuk menentukan isyarat keluarannya (Puspitaningrum D., 2006). JST ditentukan oleh 3 hal :

1. Pola hubungan antar neuron (disebut arsitektur jaringan)

2. Metode untuk menentukan bobot penghubung

3. Fungsi aktivasi. Sebagai contoh, perhatikan neuron Y pada Gambar.1.

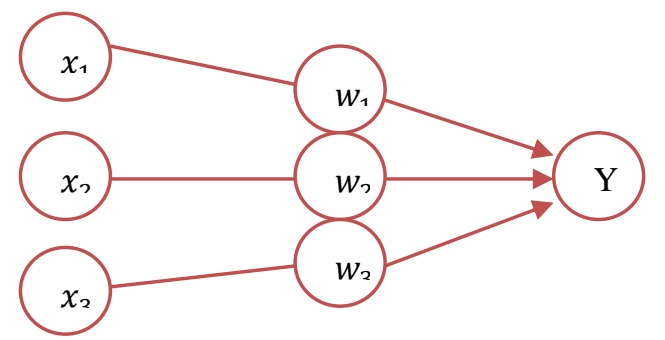

Gambar 1. Fungsi Aktivasi 
Y menerima input dari neuron $x_{1}, x_{2}, x_{3}$ dengan bobot hubungan masing-masing $w_{1}, w_{2}, w_{3}$.

Ketiga impuls neuron yang ada dijumlahkan yaitu

$$
\text { net }=x_{1} w_{1}+x_{2} w_{2}+x_{3} w_{3}
$$

Besarnya impuls yang diterima oleh Y mengikuti fungsi aktivasi $y=f(n e t)$.

\section{Konsep Dasar Jaringan Saraf Tiruan}

Setiap pola-pola informasi input dan output yang diberikan kedalam JST diproses dalam neuron. Neuron-neuron tersebut terkumpul di dalam lapisan-lapisan yang disebut neuron layers. Lapisan-lapisan penyusun JST tersebut dapat dibagi menjadi 3, yaitu :

1. Lapisan input, unit-unit di dalam lapisan input disebut unit-unit input. Unit-unit input tersebut menerima pola data dari luar yang menggambarkan suatu permasalahan.

2. Lapisan tersembunyi, unit-unit di dalam lapisan tersembunyi disebut unit-unit tersembunyi. Di mana outputnya tidak dapat secara langsung diamati.

3. Lapisan Output, unit-unit di dalam lapisan output disebut unit-unit output. Output dari lapisan ini merupakan solusi JST terhadap suatu permasalahan.

\section{Arsitektur Jaringan Saraf Tiruan}

JST memiliki beberapa arsitektur jaringan yang sering digunakan dalam berbagai aplikasi. Arsitektur JST tersebut, antara lain (Hermawan A., 2006):

1. Jaringan Lapisan Tunggal (Single Layer Network)

Jaringan dengan lapisan tunggal terdiri dari 1 lapisan input dan 1 lapisan output. Setiap neuron yang terdapat di dalam lapisan input selalu terhubung dengan setiap neuron yang terdapat pada lapisan output. Jaringan ini hanya menerima input kemudian secara langsung akan mengolahnya menjadi output tanpa harus melalui lapisan tersembunyi

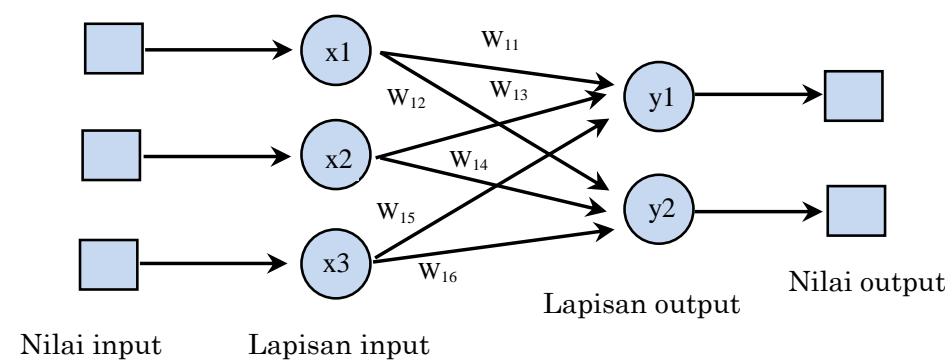

Gambar 2. Arsitektur Lapisan Tunggal

2. Jaringan Banyak Lapisan (Multilayer Net)

Jaringan dengan lapisan jamak memiliki ciri khas tertentu yaitu memiliki 3 jenis lapisan yakni lapisan input, lapisan output, dan lapisan tersembunyi. Jaringan dengan banyak lapisan ini dapat menyelesaikan permasalahan yang lebih kompleks dibandingkan jaringan dengan lapisan tunggal. Namun, proses pelatihan sering membutuhkan waktu yang cenderung lama.

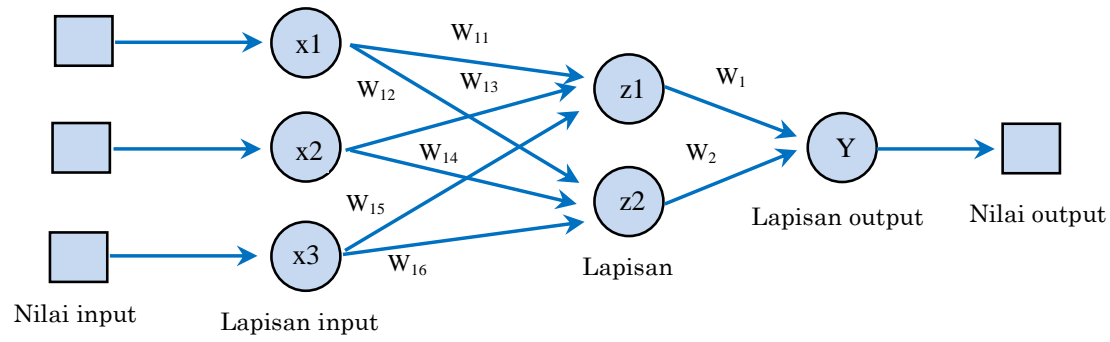

Gambar 3. Arsitektur Lapisan Multilayer 
3. Jaringan Lapisan Kompetitif (Competitive Layer)

Pada jaringan ini sekumpulan neuron bersaing untuk mendapatkan hak menjadi aktif. Contoh algoritma yang menggunakan jaringan ini adalah LVQ.

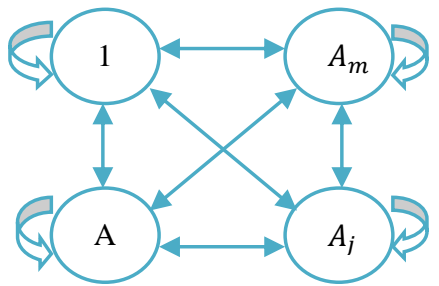

Gambar 4. Arsitektur Lapisan Kompetitif

\section{Fungsi Aktivasi Backpropagation}

Dalam backpropagation, fungsi aktivasi yang dipakai harus memenuhi beberapa syarat yaitu : kontinu, terdiferensial dengan mudah dan merupakan fungsi yang tidak turun. Salah satu fungsi yang memenuhi ketiga syarat tersebut sehingga sering dipakai adalah fungsi sigmoid biner yang memiliki range $(0,1)$. Diberikan $f(x)=\frac{1}{1+e^{-x}}$ dengan turunan $f^{\prime}(x)=$ $f(x)(1-f(x))$. Grafik fungsinya tampak pada Gambar 5.

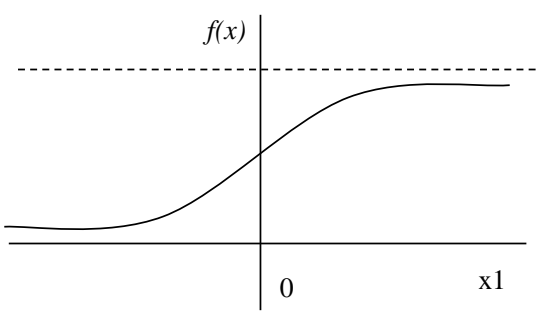

Gambar 5. Fungsi Aktivasi Sigmoid Biner

Fungsi lain yang sering dipakai adalah fungsi sigmoid bipolar yang bentuk fungsinya mirip dengan fungsi sigmoid biner, tapi dengan range $(-1,1)$. Diberikan $f(x)=\frac{2}{1+e^{-x}}-1$ dengan turunan $f^{\prime}(x)=\frac{(1+f(x))(1-f(x))}{2}$. Grafik fungsinya tampak pada Gambar 6 .

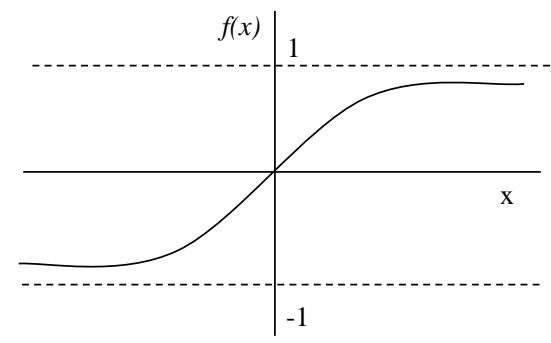

Gambar 6. Fungsi Aktivasi Sigmoid Bipolar

Fungsi sigmoid memiliki nilai maksimum $=1$. Maka untuk pola yang targetnya lebih dari 1 , pola masukan dan keluaran harus terlebih dahulu ditransformasi sehingga semua polanya memiliki range yang sama seperti fungsi sigmoid yang dipakai. Alternatif lain adalah menggunakan fungsi aktivasi sigmoid hanya pada lapisan yang bukan lapisan keluaran. Pada lapisan keluaran, fungsi aktivasi yang dipakai adalah fungsi identitas : $f(x)=x$.

\section{Pelatihan Standar Backpropagation}

Pelatihan backpropagation meliputi 3 Tahap yaitu tahap maju, propagasi mundur, dan perubahan bobot. Algoritma pelatihan untuk jaringan dengan satu lapisan tersembunyi (dengan fungsi aktivasi sigmoid biner) adalah sebagai berikut :

Langkah 0 : Inisialisasi semua bobot dengan bilangan acak kecil

Langkah 1 : Jika kondisi penghentian belum terpenuhi, lakukan langkah 2-8 
Langkah 2 : Untuk setiap pasang data pelatihan, lakukan langkah 3-8

Tahap I : Propagasi Maju

Langkah 3 :Tiap unit masukan menerima sinyal dan meneruskannya ke unit tersembunyi di atasnya

Langkah 4 : Hitung semua keluaran di unit tersembunyi $z_{j}(j=1,2, \ldots, p)$

$$
\begin{aligned}
& z_{-} n e t_{j}=v_{j o}+\sum_{i=1}^{n} x_{i} v_{j i} \\
& z_{j}=f\left(z_{-} n e t_{j}\right)=\frac{1}{1+e^{-z_{-} n e t_{j}}}
\end{aligned}
$$

Langkah 5 : Hitung semua keluaran jaringan di unit $y_{k}(k=1,2, \ldots, m)$

Tahap II : Propagasi mundur

$$
\begin{gathered}
y_{\_} n e t_{k}=w_{k o}+\sum_{j=1}^{p} z_{j} w_{k j} \\
y_{k}=f\left(y \_n e t_{k}\right)=\frac{1}{1+e^{-y_{-} n e t_{k}}}
\end{gathered}
$$

Langkah 6 : Hitung faktor $\delta$ unit keluaran berdasarkan eror di setiap unit keluaran $y_{k}(k=$ $1,2, \ldots, m)$

$$
\delta_{k}=\left(t_{k}-y_{k}\right) f^{\prime}\left(y_{-} n e t_{k}\right)=\left(t_{k}-y_{k}\right) y_{k}\left(1-y_{k}\right)
$$

$\delta_{k}$ merupakan unit eror yang akan dipakai dalam perubahan bobot lapisan di bawahnya (langkah 7)

Hitung suku perubahan bobot $w_{k j}$ (yang akan dipakai nanti untuk merubah bobot $w_{k j}$ ) dengan laju percepatan $\alpha$

$$
\Delta w_{k j}=\alpha \delta_{k} z_{j} \quad ; k=1,2, \ldots, m ; j=0,1,2, \ldots, p
$$

Langkah 7 :Hitung faktor $\delta$ unit tersembunyi berdasarkan eror di setiap unit tersembunyi $z_{j}(j=1,2, \ldots, p)$

$$
\delta \_n e t_{j}=\sum_{k=1}^{m} \delta_{j} w_{k j}
$$

Faktor $\delta$ unit tersembunyi :

$$
\delta_{j}=\delta_{-} n e t_{j} f^{\prime}\left(z_{-} n e t_{j}\right)=\delta_{-} n e t_{j} z_{j}\left(1-z_{j}\right)
$$

Hitung suku perubahan bobot $v_{j i}$ ( yang akan dipakai nanti untuk merubah bobot $\left.v_{j i}\right)$

Tahap III : Perubahan bobot

$$
\Delta v_{j i}=\alpha \delta_{j} x_{i} \quad ; j=1,2, \ldots, p ; i=0,1,2, \ldots, n
$$

Langkah 8 : Hitung semua perubahan bobot

Perubahan bobot garis yang menuju ke unit keluaran :

$$
w_{k j}(\text { baru })=w_{k j}(\operatorname{lama} a)+\Delta w_{k j}(k=1,2, \ldots, m ; j=0,1,2, \ldots, p)
$$

Perubahan bobot garis yang menuju ke unit tersembunyi :

$$
v_{j i}(\text { baru })=v_{j i}(\operatorname{lama})+\Delta v_{j i}(j=1,2, \ldots, p ; i=0,1,2, \ldots, n)
$$

Setelah pelatihan selesai dilakukan, jaringan dapat dipakai untuk pengenalan pola. Dalam hal ini, hanya propagasi maju ( langkah 4 dan 5) saja yang dipakai untuk menentukan keluaran jaringan.

Apabila fungsi aktivasi yang dipakai bukan sigmoid biner, maka langkah 4 dan 5 harus diselesaikan.Demikian juga turunannya pada langkah 6 dan 7.

Langkah 9: Uji kondisi berhenti (akhir iterasi).

\section{Hasil dan Pembahasan}

\section{Variabel yang digunakan}

Dalam penelitian ini variabel yang digunakan adalah Daftar Nilai Ebtanas Murni (NEM) siswa yang meliputi Nilai Bahasa Indonesia, Bahasa Inggris, Matematika dan Ilmu Pengetahuan Alam (IPA) sebagai data inputnya. Sedangkan Total Nilai Siswa pada semester pertama sebagai target atau outputnya (data siswa yang diambil yaitu ketika siswa bersangkutan sudah berada di kelas XII, namun data yang diambil ialah daftar nilai saat berada di kelas X siswa bersangkutan) yang didapat dari Sekolah Menengah Atas (SMA) Negeri 
4 Ambon. Seluruh data yang telah terkumpul dipisahkan menjadi 2 bagian yaitu masukan dan keluaran, yang tergolong sebagai masukan secara berurutan ialah sebagai berikut :

1. Nilai Bahasa Indonesia sebagai variabel $x_{1}$

2. Nilai Bahasa Inggris sebagai variabel $x_{2}$

3. Nilai Matematika sebagai variabel $x_{3}$

4. Nilai Ilmu Pengetahuan Alam (IPA) sebagai variabel $x_{4}$

Sedangkan yang tergolong sebagai keluaran atau target yang diinginkan adalah total nilai siswa yang bersangkutan pada semester pertama. Total nilai siswa pada semester pertama disimpan sebagai variabel $y$.

Banyaknya data untuk penelitian ini sebanyak 75 siswa, dimana 65 data (86.67\%) digunakan untuk pelatihan dan 10 data (13.33\%) digunakan untuk pengujian. Keluaran atau target yang diinginkan yaitu total nilai siswa, yang kemudian dibagi menjadi 2 pola yaitu pola $(0,0)$ untuk nilai yang berkisar antara 60 - 80 dikatakan cukup dan pola $(1,1)$ untuk nilai yang berkisar antara 81-100 dikatakan baik.

\section{Arsitektur Jaringan}

Gambar.5 menunjukkan bahwa arsitektur jaringan terdiri dari satu lapisan input yang terdiri dari 4 (empat) unit sel, 2(dua) lapisan tersembunyi dengan jumlah unit sel yang ditentukan yaitu sebanyak 10 dan 5 , dan satu lapisan output berjumlah satu unit sel sebagai target.

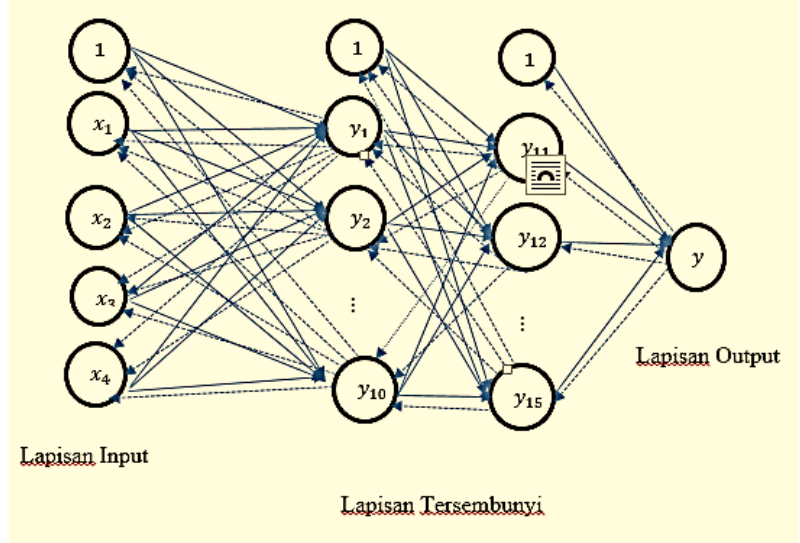

Gambar 7. Arsitektur Jaringan Untuk Memprediksi Prestasi Siswa SMA

\section{Hasil Penelitian}

Untuk memprediksi prestasi siswa dalam penelitian ini telah dirancang suatu program khusus yang dibangun dengan menggunakan toolbox yang telah disediakan MATLAB sehingga prosesnya menjadi mudah yaitu dengan menggunakan Graphical User Interface Design (GUIDe).

Untuk menggunakan aplikasi ini harus melalui 3 tahapan untuk mendapatkan keluaran prediksi prestasi siswa SMA dalam bentuk angka yaitu tahap pelatihan,tahap pengujian dan tahap prediksi.

Pada saat menggunakan GUIDe masukkan data input dan output program kedalam pelatihan dengan menggunakan callback maka akan muncul di editor. Berlaku juga untuk pengujian dan prediksi tapi dengan source code yang berbeda. Jika selesai dilakukan maka dapat digunakan untuk untuk memprediksi prestasi siswa.Untuk mendapatkan hasil tersebut diperlukan parameter sistem masukan untuk pembentukan pola. Parameter sistem dari pola yang dibentuk, yaitu :

Net Size: $\quad$ Input Layer : 4 sel

Hidden Layer : 10 sel dan 5 sel

Output Layer : 1 Sel

Maksimum epoch / iterasi : 50000 
Show Epoch : 25

Learning Rate : 0.001

Momentum : 0.8

Goal / Target : 0.00001

Bobot : -1 sampai dengan 1

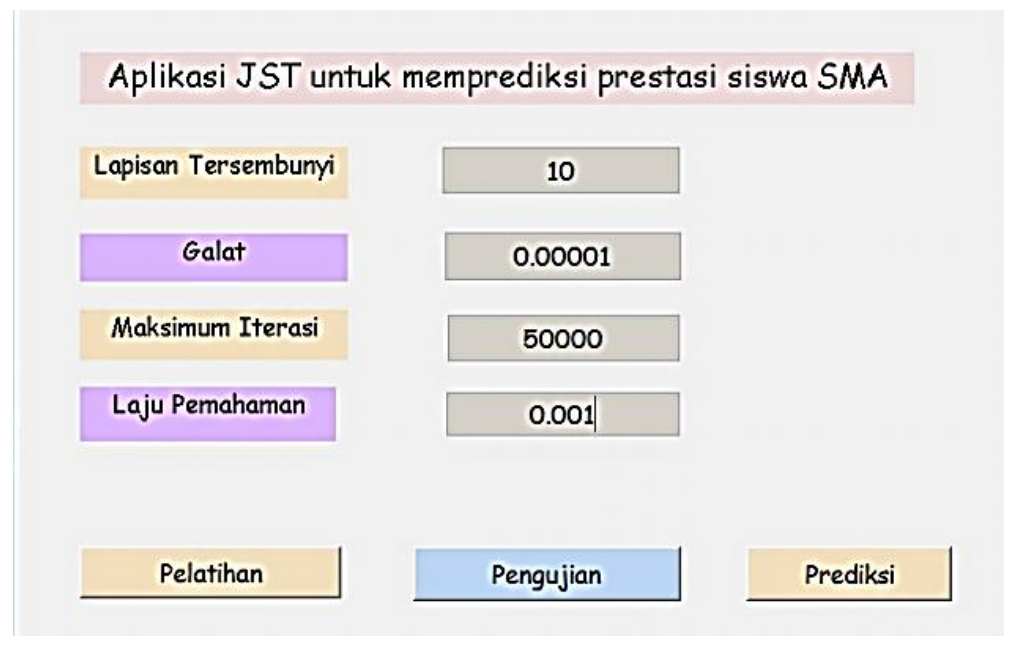

Gambar 8. Tampilan Aplikasi dalam GUI

Data akan langsung dilatihkan dan menghasilkan neural network training sebagai berikut:

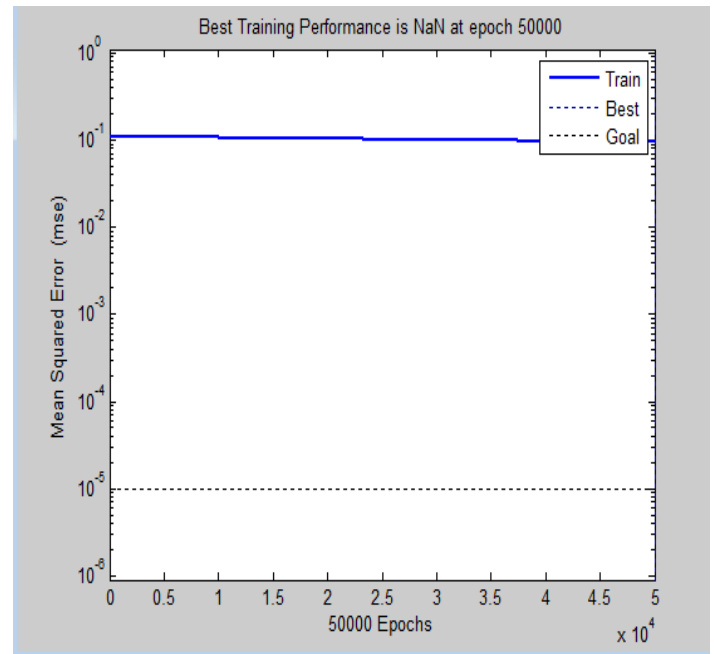

(i)

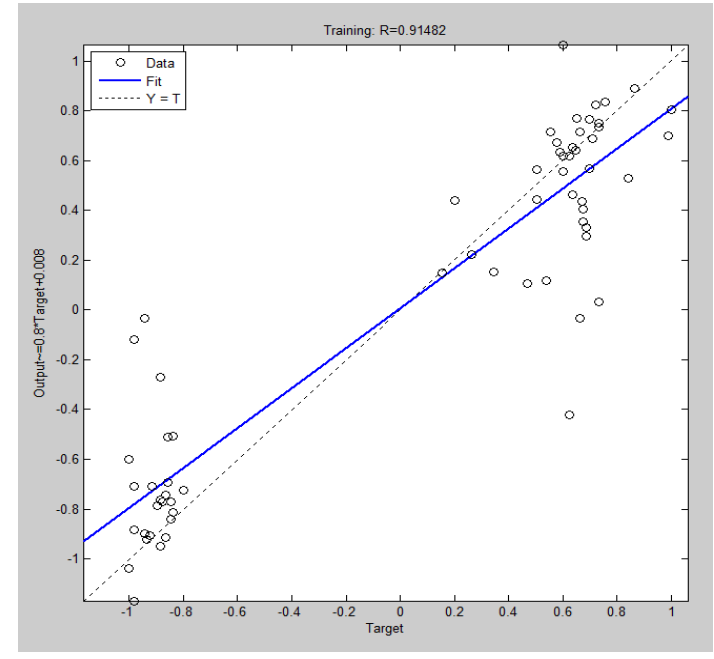

(ii)

Gambar.9. Hasil Neural Network berupa (i) plot perform, dan (ii) plot regression.

Berdasarkan Gambar.7 dapat diketahui hasil dari proses JST backpropagation yang ditampilkan dalam bentuk grafik. Pada Gambar.7(i) menunjukkan proses pembelajaran pada setiap epoch. Pada proses ini, iterasi dihentikan pada epoch ke-50000, karena batas dari epoch yang diinginkan sudah tercapai dan (MSE $=0.000000948<0.00001)$ dimana MSE ini merupakan MSE yang muncul ketika pelatihan selesai dilakukan sesuai dengan iterasi yang ditentukan. Gambar.7(ii) menunjukkan hubungan antara target dengan output jaringan pada data pelatihan. Dari pengujian pada data pelatihan untuk kecocokan antara output jaringan dengan target diperoleh koefisien korelasi (R) bernilai 0,91482 dimana untuk hasil terbaik adalah bernilai 1 .

Setelah melakukan pengujian dan pelatihan, klik prediksi maka didapat hasil seperti lampiran output. Di dalam pelatihan nilai bobot dan bias awal ditentukan dengan bilangan acak kecil 
agar mendapatkan error yang minimum, agar hasil prediksi tidak berubah - ubah, karena jika tidak diberi batasan nilai bobot dan biasnya maka output jaringannya akan berubah-ubah setelah membentuk jaringan jika dilakukan pelatihan berulang kali meskipun dengan lapisan tersembunyi yang sama. Setelah melakukan pengujian dan pelatihan didapat hasil sebagai berikut :

Tabel 1. Data Hasil Pelatihan

\begin{tabular}{|c|c|c|c|}
\hline No & Target & Prediksi & Error \\
\hline 1 & 86.45 & 86.5828 & -0.1328 \\
\hline 2 & 84.27 & 82.8078 & 1.4622 \\
\hline 3 & 85.18 & 82.471 & 2.709 \\
\hline 4 & 83.64 & 83.3453 & 0.2947 \\
\hline 5 & 86.54 & 86.5016 & 0.0384 \\
\hline 6 & 86.36 & 78.4824 & 7.8776 \\
\hline 7 & 86.18 & 85.8425 & 0.3375 \\
\hline 8 & 87.18 & 87.1858 & -0.0058 \\
\hline 9 & 85.45 & 85.0052 & 0.4448 \\
\hline 10 & 86.82 & 83.8915 & 2.9285 \\
\hline 11 & 86.73 & 84.6963 & 2.0337 \\
\hline 12 & 87.36 & 87.9508 & -0.5908 \\
\hline 13 & 86.18 & 89.658 & -3.478 \\
\hline 14 & 83.18 & 84.9832 & -1.8032 \\
\hline 15 & 86.72 & 84.9319 & 1.7881 \\
\hline 16 & 86.91 & 87.4356 & -0.5256 \\
\hline 17 & 86.64 & 81.4097 & 5.2303 \\
\hline 18 & 88.18 & 88.3608 & -0.1808 \\
\hline 19 & 87.18 & 87.3197 & -0.1397 \\
\hline 20 & 82.82 & 82.7706 & 0.0494 \\
\hline 21 & 86.45 & 85.157 & 1.293 \\
\hline 22 & 87.18 & 81.9029 & 5.2771 \\
\hline 23 & 88 & 85.6474 & 2.3526 \\
\hline 24 & 87 & 86.8442 & 0.1558 \\
\hline 25 & 86.82 & 84.1668 & 2.6532 \\
\hline 26 & 86.18 & 86.3148 & -0.1348 \\
\hline 27 & 86.55 & 87.4485 & -0.8985 \\
\hline 28 & 86 & 86.731 & -0.731 \\
\hline 29 & 86.55 & 87.4491 & -0.8991 \\
\hline 30 & 85.45 & 85.9215 & -0.4715 \\
\hline 31 & 85.82 & 87.043 & -1.223 \\
\hline 32 & 89.19 & 87.7208 & 1.4692 \\
\hline 33 & 86.73 & 84.3452 & 2.3848 \\
\hline
\end{tabular}

\begin{tabular}{|c|c|c|c|}
\hline No & Target & Prediksi & Error \\
\hline 34 & 86.91 & 85.9484 & 0.9616 \\
\hline 35 & 86.36 & 86.3267 & 0.0333 \\
\hline 36 & 86.64 & 87.0578 & -0.4178 \\
\hline 37 & 86.09 & 86.4465 & -0.3565 \\
\hline 38 & 85.73 & 82.5495 & 3.1805 \\
\hline 39 & 89.09 & 86.9202 & 2.1698 \\
\hline 40 & 87.09 & 87.876 & -0.786 \\
\hline 41 & 74.58 & 81.4032 & -6.8232 \\
\hline 42 & 75.36 & 77.8486 & -2.4886 \\
\hline 43 & 75.36 & 75.5359 & -0.1759 \\
\hline 44 & 75.14 & 76.0632 & -0.9232 \\
\hline 45 & 75.21 & 76.4626 & -1.2526 \\
\hline 46 & 74.71 & 74.8395 & -0.1295 \\
\hline 47 & 75.64 & 76.2189 & -0.5789 \\
\hline 48 & 74.78 & 76.3336 & -1.5536 \\
\hline 49 & 74.92 & 75.7404 & -0.8204 \\
\hline 50 & 75 & 79.6245 & -4.6245 \\
\hline 51 & 75.29 & 75.3284 & -0.0384 \\
\hline 52 & 75 & 75.9299 & -0.9299 \\
\hline 53 & 74.14 & 73.8387 & 0.3013 \\
\hline 54 & 74.29 & 80.7776 & -6.4876 \\
\hline 55 & 75.29 & 75.878 & -0.588 \\
\hline 56 & 74.29 & 76.339 & -2.049 \\
\hline 57 & 74.29 & 72.8751 & 1.4149 \\
\hline 58 & 75.14 & 74.7839 & 0.3561 \\
\hline 59 & 74.14 & 77.144 & -3.004 \\
\hline 60 & 74.29 & 75.0208 & -0.7308 \\
\hline 61 & 74.64 & 74.7418 & -0.1018 \\
\hline 62 & 75.07 & 75.8538 & -0.7838 \\
\hline 63 & 75 & 74.5384 & 0.4616 \\
\hline 64 & 74.57 & 74.907 & -0.337 \\
\hline 65 & 75.21 & 77.8348 & -2.6248 \\
\hline
\end{tabular}

Dari pelatihan jaringan yang dilakukan, didapatkan nilai MSE (Mean Square Error) yaitu:

$$
M S E=\frac{\sum_{i=1}^{65} e^{2}}{n}=\frac{348.9075}{65}=5.367804
$$

Hal ini berarti bahwa jaringan sudah mampu belajar dengan baik untuk menghasilkan target yang diinginkan. 


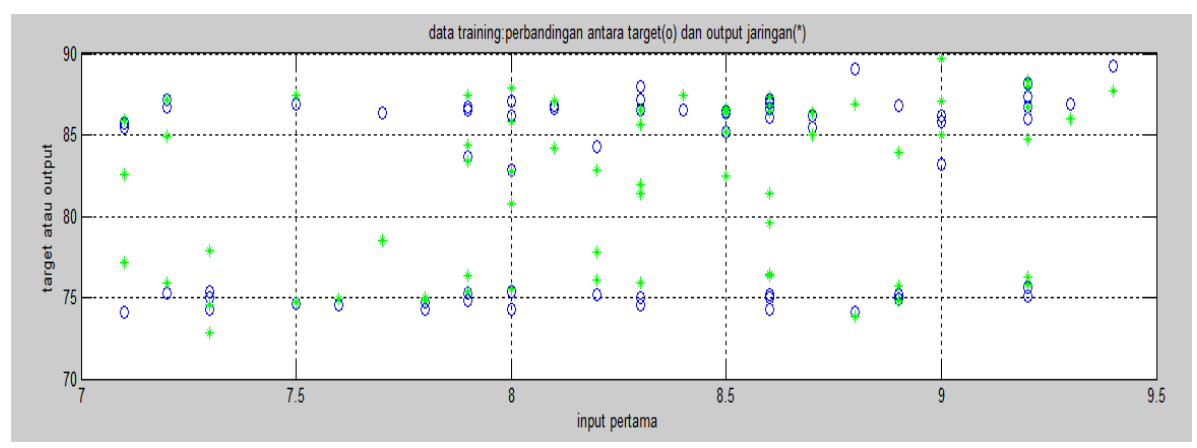

Gambar 10. Grafik Hasil Pelatihan untuk inputan pertama

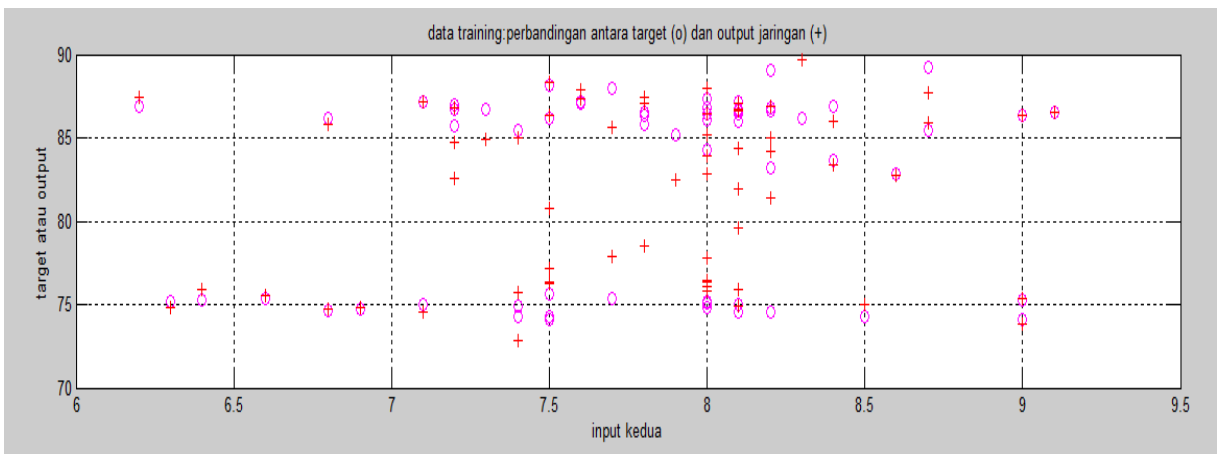

Gambar 11. Grafik Hasil Pelatihan untuk inputan kedua

Pada Gambar 10 dan 11, menunjukkan perbandingan antara target dengan output jaringan pada data pelatihan. Pada gambar dapat dilihat bahwa sebagian besar output jaringan (o) dan target (*) sudah berdekatan (hampir menempati posisi yang sama). Untuk hasil yang terbaik terjadi apabila posisi (o) dan (*) tepat berada pada posisi yang sama, tetapi ada juga yang tidak menempati posisi yang sama antara target dan prediksi, itu dikarenakan tingkat error yang signifikan saat pelatihan. Adapun data Hasil Pengujian sebagai berikut :

Tabel 2. Data Hasil Pengujian

\begin{tabular}{|c|c|c|c|}
\hline No & Target & Prediksi & Error \\
\hline 1 & 75.14 & 80.5243 & -5.3843 \\
\hline 2 & 74.5 & 78.282 & -3.782 \\
\hline 3 & 74.21 & 75.059 & -0.849 \\
\hline 4 & 76 & 73.5436 & 2.4564 \\
\hline 5 & 75.29 & 87.0143 & -11.7243 \\
\hline
\end{tabular}

\begin{tabular}{|c|c|c|c|}
\hline No & Target & Prediksi & Error \\
\hline 6 & 74.86 & 73.233 & 1.627 \\
\hline 7 & 74.29 & 83.7647 & -9.4747 \\
\hline 8 & 75.21 & 73.3118 & 1.8982 \\
\hline 9 & 74.5 & 74.934 & -0.434 \\
\hline 10 & 75.64 & 85.3977 & -9.7577 \\
\hline
\end{tabular}

Dari pengujian jaringan yang dilakukan, didapatkan nilai MSE (Mean Square Error) yaitu:

$$
M S E=\frac{\sum_{i=1}^{65} e^{2}}{n}=\frac{378.9294}{10}=37.89294
$$

terhadap 10 data yang diuji. 


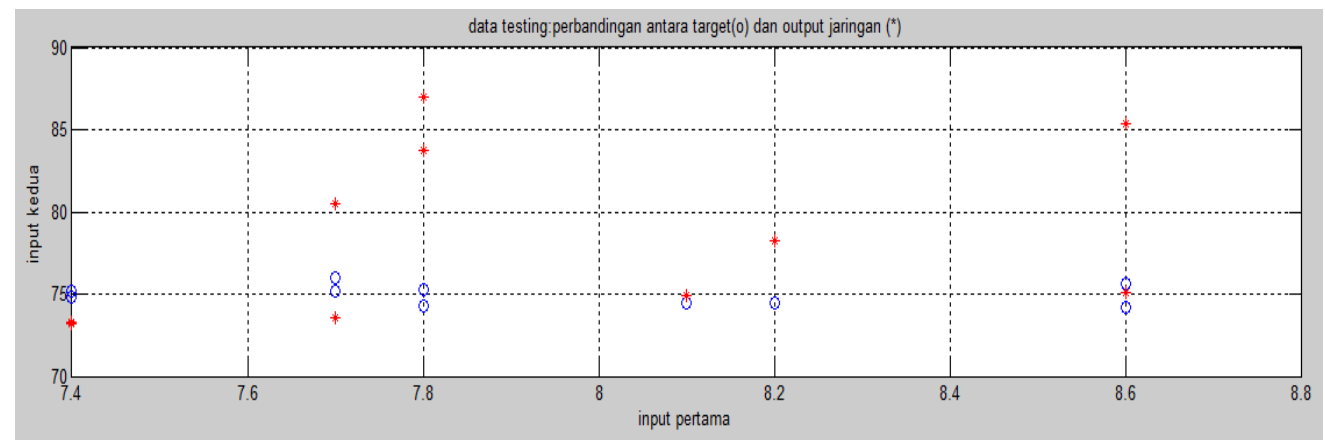

Gambar 12. Grafik Hasil Pegujian inputan pertama

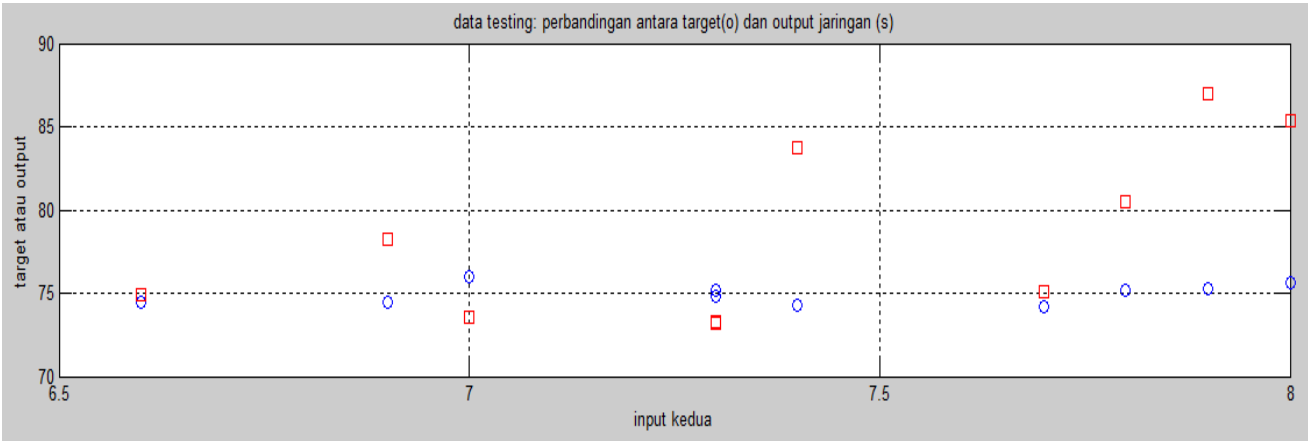

Gambar 13. Grafik Hasil Pegujian inputan kedua

Pada Gambar 12 dan 13 menunjukkan perbandingan antara target dengan output jaringan pada data pegujian. Pada gambar dapat dilihat bahwa sebagian output jaringan (o) dan target (*) sudah berdekatan (hampir menempati posisi yang sama), dan sebagian besar belum mendekati target. Untuk hasil yang terbaik terjadi apabila posisi (o) dan ${ }^{*}$ ) tepat berada pada posisi yang sama, Jika berdekatan itu artinya jaringan sudah dapat memprediksi dengan tepat.

\section{Hasil Prediksi}

Berdasarkan hasil visualisasi grafik-grafik yang diberikan, dapat dilihat bahwa hasil pengenalan pola data oleh Jaringan Syaraf Tiruan backpropagation akan lebih baik jika menggunakan tingkat error yang lebih kecil. Hal ini membuktikan bahwa Jaringan Syaraf Tiruan sangat kuat dalam mengenal pola-pola data yang diberikan. Hal ini berarti semakin kecil target error yang diinginkan, berarti akan semakin kecil penyimpangan hasil ramalan dengan hasil yang diinginkan, sehingga ketepatan model peramalan hasil pelatihan jaringan akan semakin tinggi.

Berikut adalah hasil perbandingan antara target yang diharapkan dan target hasil prediksi yang sudah dimasukkan dalam pengelompokkan Nilai :

Tabel 3. Tabel Pengelompokkan Hasil Pelatihan dan Hasil Pengujian Jaringan

\begin{tabular}{|c|c|c|c|c|c|c|}
\hline No & T & P & Target & $\begin{array}{c}\text { Hasil } \\
\text { Pengujian }\end{array}$ & $\begin{array}{c}\text { Kondisi } \\
\text { Sebenarnya }\end{array}$ & $\begin{array}{c}\text { Ketepatan } \\
\text { Jaringan }\end{array}$ \\
\hline 1 & 75.14 & 80.5243 & 0,0 & 1,1 & Cukup & Salah \\
\hline 2 & 74.5 & 78.282 & 0,0 & 0,0 & Cukup & Benar \\
\hline 3 & 74.21 & 75.059 & 0,0 & 0,0 & Cukup & Benar \\
\hline 4 & 76 & 73.5436 & 0,0 & 0,0 & Cukup & Benar \\
\hline 5 & 75.29 & 87.0143 & 0,0 & 1,1 & Cukup & Salah \\
\hline 6 & 74.86 & 73.233 & 0,0 & 0,0 & Cukup & Benar \\
\hline 7 & 74.29 & 83.7647 & 0,0 & 1,1 & Cukup & Salah \\
\hline 8 & 75.21 & 73.3118 & 0,0 & 0,0 & Cukup & Benar \\
\hline 9 & 74.5 & 74.934 & 0,0 & 0,0 & Cukup & Benar \\
\hline 10 & 75.64 & 85.3977 & 0,0 & 1,1 & Cukup & Salah \\
\hline
\end{tabular}


Hasil yang didapat dari penelitian ini adalah dapat dijelaskan bahwa total nilai semester 1 kelas X atau prestasi siswa tidak dapat diukur secara keseluruhan menggunakan nilai NEM saat SMP. Karena eror yang didapat saat pelatihan dan pengujian terlihat erornya cukup kecil yang menyebabkan prediksinya dikatakan baik, setelah melakukan pelatihan berulang kali sehingga didapat eror yang baik seperti pada Tabel.1 di atas. Dan dapat dilanjutkan ke pengujian data baru, yang menghasilkan 60\% target prediksi sesuai dengan error yang minimum. Berdasarkan hasil tersebut menunjukkan bahwa NEM tidak selalu berkorelasi positif dengan prestasi yang dicapai siswa selama mengikuti proses belajar mengajar di sekolah. Hal ini mungkin dikarenakan masih banyaknya faktor lain yang mengganggu dan mempengaruhi proses belajar saat di Sekolah. Seperti faktor guru pengajar, lingkungan, fasilitas, kebiasaan, dan lain sebagainya.

\section{Simpulan}

Berdasarkan penelitian yang dibuat, dapat ditarik kesimpulan bahwa dengan tingkat korelasi kecocokan antara target yang telah ditentukan dan target hasil prediksi sebesar $60 \%$ maka NEM tidak selalu dapat dijadikan patokan untuk siswa yang berprestasi. Hal ini dapat disebabkan lebih dari 159 factor internal maupun eksternal selama menjadi seorang siswa.

\section{Daftar Pustaka}

1. Agustin, M., Penggunaan Jaringan Saraf Tiruan Backpropagation Untuk Seleksi Penerimaan Mahasiswa Baru Pada Jurusan Teknik Komputer di Politeknik Negeri Sriwijaya.Tesis. Program Studi Magister Sistem Informasi, (2012).

2. Away, Gunaidi A., Matlab Programming.Bandung : Informatika (2006).

3. Azadekh, dkk., Peramalan Konsumsi Listrik Tahunan Menggunakan Jaringan Saraf Tiruan di Sektor Industri. Diakses pada tanggal 1 Januari 2015, (2008).

4. Hermawan, A., Jaringan Saraf Tiruan dan Aplikasinya.Yogyakarta: Andi, (2006).

5. Laurene F., Fundamental of Neural Networks, Architectures, Algorithms, and Applications, Prentice Hall, Upper Saddle River, New Jersey, (1994).

6. Matondang \& Zekson A., Jaringan Saraf Tiruan dengan Algoritma Backpropagation untuk Penentuan Sidang Skripsi. Jurnal STMIK Budi Darma Medan, (2013).

7. Puspitaningrum D., Pengantar Jaringan Syaraf Tiruan, Penerbit Andi Yogyakarta, (2006).

8. Siang, Jong Jek., Jaringan Saraf Tiruan dan Pemrogramannya Menggunakan Matlab.Yogyakarta: Andi (2009). 
Y. A. Lesnussa, et al / JMI Vol 11 No 2, Oktober 2015, Pp. 149 - 160 